\title{
CONTENTS VOLUME 9 (1991)
}

Editorial

Overcoming obstacles to university and industry synergy in system education: lessons from action research J.T. NOSEK and G. YAVERBAUM

Education for information management: restructuring and reform W.J. MARTIN

The Applied Information Management program: multidisciplinary continuing higher education L.F. ETTINGER

Curriculum aspects of a teaching module on database construction J.H.E. VAN DER STARRE

Computer methods in the teaching of library and information studies

F. ROWLAND and G.M. TSENG

Training for rural library and community information centre management (Short Communication) E.N.O. ADIMORAH

Book Reviews

News

$\begin{array}{lr}\text { Calendar of Events } & 91\end{array}$

Editorial

Training staff and end-users for automated retrieval systems in the health sciences J.B. HEPWORTH

Expert systems teaching and research in North American LIS Schools

A. MORRIS and S. HUTTON

Characteristics and careers of past post-graduate diploma students of the Department of Library and Archival Studies, University of Ghana, Legon, 1981/82-1987/88

\section{A.A. ALEMNA}

Making the transparent visible: an activity to demonstrate some of the concepts of information service and product design

H. YERBURY, M. COOMBS and R. McGRATH

Selection and preparation of research students at DLIS Loughborough (Short Communication) H. BATEMAN and P. STURGES

Book Reviews

News

Seminar Reports 
Annual Bibliography, 1990: Education and training for librarianship and information work

A.J. CLARK

A field test of the Library of Congress 'Training the Trainer' course

S.S. INTNER

Education for Information Science in China (Short Communication)

P. LEE

Book Reviews

News

Editorial

Learning by others' experience: An analysis of Library Journal Cases 1983-1989

J. ERKKILA and M. ERKKILA

The college of information science: a mechanism to consolidate information science education G.A. FORGIONNE

The role of distance education in library and information studies education J.A. HAYTHORNTHWAITE and F.C.P. WHITE

Education for teacher-librarianship in Australia K. BEATTIE and J. HENRI

The postgraduate course in information engineering at Jilin University of Technology (JUT) (Short Communication)

J. JIPENG, J. DUANFANG and Z. ZHONGLIAN

Book Reviews

News

Author Index Volume 9

Contents Volume 9 